Zeszyty Naukowe Szkoły Głównej Gospodarstwa Wiejskiego

Ekonomika i Organizacja Gospodarki Żywnościowej nr 109, 2015: 107-121

Maria Zuba-Ciszewska

Katedra Bankowości i Finansów

Katolicki Uniwersytet Lubelski Jana Pawła II

\title{
Wpływ koncentracji kapitału własnego na jego efektywność w wybranych spółdzielniach mleczarskich w Polsce w latach 2003-2012
}

\section{Wstęp}

Polska branża mleczarska jest silnie rozdrobniona, co jest jej słabą stroną. W 1994 roku przerobem mleka i obrotem artykułami mlecznymi zajmowało się 336 podmiotów, w tym 309 spółdzielni mleczarskich, a w 2007 roku 238 przedsiębiorstw, w tym 188 spółdzielni. Obecnie ich liczba wynosi około 188 [Rynek mleka 2014, s. 11], w tym 75\% to spółdzielnie. Od początku okresu transformacji w latach dziewięćdziesiątych XX wieku likwidowane były przede wszystkim małe przedsiębiorstwa, które nie sprostały wymogom konkurencji rynkowej oraz oczekiwaniom klientów. Rozpoczął się wtedy proces koncentracji przetwórstwa mleka, racjonalizacji jego struktur produkcyjnych oraz modernizacji zakładów przetwórczych [Seremak-Bulge 2005, s. 117; Pietrzak 2006, s. 74, Falkowski i in. 2007, s. 96]. Koncentrację i specjalizację produkcji oraz przetwórstwa uznano za podstawę wzrostu efektywności gospodarki mleczarskiej [Brodziński 2014, s. 133]. Waga tych procesów jest wciąż aktualna [Kapusta 2011, s. 44]. Wzrost koncentracji i związany z tym postęp technologiczny jest szansą rozwoju sektora mleczarskiego [Seremak-Bulge 2013, s. 40]. Wraz z postępującą restrukturyzacją sektora mleczarskiego, dzięki przewagom konkurencyjnym, może się zwiększać eksport produktów mleczarskich [Komorowska 2006, s. 160; Szajner 2011, s. 159]. Czynnikiem wzrostu eksportu polskich produktów mleczarskich jest ich wysoka jakość i znaczny udział wartości dodanej [Szczubełek 2011, s. 119].

Przykładem postępującej koncentracji w przemyśle mleczarskim mogą być dwie największe spółdzielnie mleczarskie w Polsce (Mlekpol z Grajewa i Mlekovita z Wysokiego Mazowieckiego). W 2004 roku miały one udział w skupie 
mleka na poziomie $18 \%$, a w 2013 roku już $26 \%{ }^{1}$. Stąd w warunkach postępującej koncentracji $\mathrm{w}$ polskim przemyśle mleczarskim zachodzi potrzeba badań korzyści ekonomicznych z powiększających się podstawowych czynników produkcji mleczarni, w tym ich kapitału własnego. Kapitały własne są najbardziej stabilną podstawą finansowania działalności przedsiębiorstwa, decydującą w istotnej mierze o stopniu utrzymania płynności finansowej. Ich wysokość stanowi dla wierzycieli informację, do jakiej kwoty podmiot zdolny jest ponosić konsekwencje finansowe w razie powstania strat. Kapitał własny stanowi równowartość zasobów majątkowych podmiotu, którymi on dysponuje w całym swoim okresie działalności [Nowak 2005, s. 80]. Jedną z najważniejszych pozycji kapitału własnego jest kapitał (fundusz) podstawowy, który w spółdzielni przyjmuje postać funduszu udziałowego. Jest on tworzony z majątku powstałego $\mathrm{z}$ wniesionych wpłat członkowskich lub nieodebranej ze spółdzielni nadwyżki bilansowej. Utworzona przez fundusz udziałowy część majątku jest tzw. majątkiem wolnym, nieobciążonym długami [Kruczalak 1996, s. 156]. Może być on jednak zmniejszony w wyniku poniesienia przez spółdzielnię strat lub zmniejszenia liczby członków spółdzielni, na rzecz których w wyniku ustania stosunku członkostwa należy dokonać zwrotu wpłat. Zmienność funduszu udziałowego wynikająca ze zmienności składu członkowskiego jest słabością tego funduszu. Ta zmienność funduszu udziałowego jest jednak konsekwencją jednej z najistotniejszych cech spółdzielni, tzn. nieograniczoności liczby członków. To sprawia, że fundusz udziałowy ma podstawowe znaczenie dla spółdzielni [Zakrzewski 2003, s. 97]. Jak pokazują badania członków spółdzielni mleczarskiej, większa liczba dostawców mleka wpływa dodatnio na poziom jej rentowności [Zuba i Zuba 2012, s. 618]. Wynika to z rozdrobnionej bazy surowcowej w kraju (produkcję mleka w 2010 roku prowadziło aż 453,9 tys. gospodarstw rolnych [GUS 2012, s. 110]). Spowodowane jest to stosunkowo małą liczbą krów mlecznych w tych gospodarstwach (średnio 5,6 sztuk). Z drugiej strony wśród czynników ekonomicznych wpływających na rozwój gospodarstwa utrzymującego krowy wpływa jego bliższe otoczenie [Parzonko 2013, s. 144], do którego zaliczyć można spółdzielnię mleczarską. Przez fundusz udziałowy wyraża się związek majątkowy członka ze spółdzielnią. W momencie rozpoczynania działalności spółdzielni członek uczestniczy w tworzeniu tego podstawowego funduszu. Fundusz udziałowy pełni również funkcję finansową (gospodarczą). Oznacza ona, że wpłaty członkowskie są przeznaczone na rozpoczęcie i prowadzenie działalności gospodarczej odpowiadającej celom spółdzielni określonym w statucie, a zgodnym $z$ ustawą o prawie spółdzielczym (art. 1). Pełni on także funkcję

\footnotetext{
${ }^{1}$ Obliczenia własne na podstawie danych ze stron www obydwu mleczarni i danych GUS nt. wielkości skupu mleka w Polsce.
} 
gwarancyjną. Jest to konsekwencja istniejącej w prawie cywilnym zasady bezpieczeństwa obrotu, której najważniejszym przejawem jest ochrona praw osób trzecich [Stelmachowski 1998, s. 102]. Spółdzielnia powinna dążyć więc do tego, aby majątek odpowiadający wysokości funduszu został w niej utrzymany ${ }^{2}$. Większość funduszu udziałowego w spółdzielniach składa się w przeważającej części z nieulokowanych funduszy (kolektywna własność kapitału), które wykorzystane efektywnie przyczyniają się do zwiększenia zysków [Mierzwa 2005, s. 78]. Te z kolei pośrednio mogą być wypłacane rolnikom-dostawcom w postaci np. wyższej ceny za mleko lub zostać zainwestowane w majątek trwały i rozwój spółdzielni [Dworniak i Wasilewski 2007, s. 119]. Badania potwierdzaja, że spółdzielnie mleczarskie o wyższych funduszach własnym i udziałowym płaca rolnikom wyższą cenę za mleko [Dworniak 2009, s. 31] i osiągają większą rentowność sprzedaży [Dworniak 2010, s. 212]. Kapitał (fundusz) zapasowy jest również obligatoryjną częścią kapitału (funduszu) własnego. W przypadku spółdzielni nosi nazwę funduszu zasobowego. Powstaje z wpłat wpisowego i części nadwyżki bilansowej [ustawa Prawo spółdzielcze, art. 78]. Podobnie jak fundusz udziałowy pełni on funkcję finansowania działalności i funkcję gwarancyjna. Funkcje te przejawiają się w taki sam sposób jak w przypadku funduszu udziałowego. Dodatkowo w przypadku funkcji gwarancyjnej oznacza ona, że fundusz ten zostaje użyty do pokrycia strat spółdzielni przed kapitałami obcymi. Aby uniezależnić spółdzielnię od zmieniającego się składu członków, potrzebne jest zebranie nienaruszalnego, niezwrotnego, niezmiennego majątku [Janczewski 1990, s. 278]. Fundusz zasobowy ma więc wzmocnić materialne podstawy spółdzielni. Jego niepodzielność wynika z założeń konstrukcyjnych spółdzielni, których przestrzeganie umożliwia spółdzielni działanie. W odniesieniu do funduszu zasobowego obowiązuje bowiem zasada utrzymania ${ }^{3}$. Stałość funduszu zasobowego polega na tym, że jego wysokość może ulegać zwiększeniu (np. po przystąpieniu nowych członków do spółdzielni wzrastają wszystkie udziały wniesione), ale nie może ulegać obniżeniu (z wyjątkiem sytuacji, gdy spółdzielnia poniesie stratę i zostaje ona pokryta kosztem tego funduszu).

Bezpieczeństwo przemysłu mleczarskiego naszego kraju w warunkach nasilonej konkurencji oraz niepewnej sytuacji gospodarczej (m.in. brak wyraźnego

\footnotetext{
${ }^{2}$ Przejawia się to w tym, że fundusz ten jest chroniony przed naruszeniami, czyli wyprowadzeniem go na rzecz członków spółdzielni (lub osób trzecich), poza tymi przypadkami, w których prawo na to wyraźnie zezwala. - por. art. 21 ustawy z dnia z 16 września 1982 r. Prawo spółdzielcze (Dz.U. z 1995 r. nr 54, poz. 288 z późn. zm.)

${ }^{3}$ Polega ona na tym, że część majątku spółdzielni, która odpowiada funduszowi zasobowemu, w okresie działalności spółdzielni nie może trafić do jej członków czy do osób trzecich, chyba że przepisy ustawy o prawie spółdzielczym wyraźnie na to zezwalają - art. 26, art. 125 ustawy Prawo spółdzielcze.
} 
wyeliminowania skutków kryzysu finansowego oraz zagrożenia znacznego eksportu żywności Polski na wschód) nabiera coraz większego znaczenia, szczególnie dla spółdzielni mleczarskich. Te z racji ich pełnionych misji oraz realizowanych celów ekonomicznych i społecznych bezpieczeństwo finansowe traktują jako swój główny priorytet. Bez niego nie mogą być bezpiecznymi i wiarygodnymi podmiotami, stwarzającymi realne korzyści ekonomiczne swoim członkom oraz interesariuszom. Przetrwanie i rozwój są zatem szczególnie istotne dla spółdzielni mleczarskich z wielu względów, m.in.: rolniczych, ekonomicznych i społecznych oraz bezpieczeństwa żywnościowego. Udział spółdzielni mleczarskich w skupie mleka krowiego w kraju w 2012 roku wynosił bowiem 66,4\% [GUS 2013, s. 258]. Ten duży udział spółdzielni mleczarskich wynika z ich statutu, aby zapewnić sprzyjające, dogodne dla członków spółdzielni warunki rozwoju produkcji mleka oraz jego sprzedaży [Brodziński 1993, s. 97, 98]. Uzyskiwane korzyści przez członków spółdzielni ze sprzedaży ich mleka związane są ze spełnieniem koniecznego warunku członkostwa, tj. wniesieniem odpowiedniej wartości udziału (kapitału) do tej spółdzielni mleczarskiej. Stąd wielkość wartości wniesionych udziałów kapitału własnego członków do spółdzielni mleczarskiej stanowi dla zarządu jeden z podstawowych warunków prowadzenia rentownej i finansowo bezpiecznej działalności gospodarczej.

\section{Materiał i metodyka}

Celem badań była analiza i ocena wpływu koncentracji kapitału własnego na jego efektywność na przykładzie SM Mlekovita oraz SM Mlekpol (oznaczone w pracy odpowiednio I i II). Do badań wykorzystano dokumenty źródłowe w postaci sprawozdań finansowych (bilansów, rachunku zysków i strat) publikowanych w „Monitorze Spółdzielczym B”. Zakres czasowy analizy obejmował lata 2003-2012 i został podzielony na dwa równe podokresy, po 5 lat, przed kryzysem finansowym i po nim. Celem metodycznym była próba odpowiedzi na pytanie, czy kryzys finansowy miał wpływ na proces koncentracji w analizowanych spółdzielniach mleczarskich. Ze względu na dostępność danych ostatnim rokiem badań był 2012 rok. Zjawisko koncentracji kapitału własnego zostało przedstawione za pomocą wartości bezwzględnych oraz wskaźników jego struktury, a efektywność tego kapitału za pomocą wskaźnika jego rentowności (ROE), dźwigni finansowej oraz modelu du Ponta. Oprócz tych standardowych kryteriów oceny efektywności rozpatrywanego kapitału, opracowano i zastosowano wskaźnik produktywności kapitału własnego ogółem i jego podstawowych składników. W pracy wykorzystano analizy: porównawczą, wskaźnikową, korelacji oraz przyczynowo-skutkową. Przy prezentacji wyników badań wykorzy- 
stano metodę opisową i zestawień tabelarycznych. Wybór wyżej wymienionych spółdzielni mleczarskich do badań wynikał z tego, że są to dwie największe spółdzielnie mleczarskie w Polsce [Lista 2000..., 2013, s. 27]. Spółdzielnia mleczarska „Mlekpol” posiada 12 zakładów produkcyjnych [Mlekpol], a spółdzielnia mleczarska „Mlekovita” 13 [Mlekovita, www].

\section{Wyniki badań}

W okresie 2003-2012 Mlekovita powiększyła swój kapitał własny 5,7 razy - do wartości ponad 0,50 mld zł, a Mlekpol 3,7 razy - do poziomu 0,72 mld zł (tab. 1). Przy czym Mlekovita odnotowała większą dynamikę wzrostu zarówno w okresie przed kryzysem finansowym, jak i po nim.

Fundusz udziałowy w Mlekovicie zwiększył się dwukrotnie - do poziomu ponad $86 \mathrm{mln}$ zł, a w Mlekpolu czterokrotnie - do wartości 0,58 mld zł. O ile w latach 2003-2007 tempo wzrostu omawianego funduszu było większe

\section{Tabela 1}

Wartość kapitału własnego i jego wybranych składowych [mln zł] badanych spółdzielni w latach 2003-2012 oraz ich dynamika [\%]

\begin{tabular}{|c|c|c|c|c|c|c|}
\hline \multirow{2}{*}{ Lata i dynamika } & \multicolumn{2}{|c|}{ KW } & \multicolumn{2}{c|}{ FU } & \multicolumn{2}{c|}{ FZ } \\
\cline { 2 - 7 } & SM I & SM II & SM I & SM II & SM I & SM II \\
\hline 2003 & 88,39 & 196,76 & 42,68 & 142,83 & 35,68 & 54,49 \\
\hline 2004 & 115,25 & 248,01 & 44,33 & 179,38 & 43,67 & 67,42 \\
\hline 2005 & 146,53 & 308,70 & 49,52 & 224,76 & 60,93 & 91,71 \\
\hline 2006 & 172,90 & 365,34 & 51,65 & 264,60 & 81,43 & 113,94 \\
\hline 2007 & 215,50 & 435,71 & 50,46 & 295,57 & 108,74 & 125,30 \\
\hline 2008 & 274,61 & 516,27 & 57,92 & 418,45 & 153,01 & 155,36 \\
\hline 2009 & 340,23 & 578,29 & 67,15 & 512,79 & 208,99 & 177,18 \\
\hline 2010 & 391,83 & 623,21 & 72,13 & 486,89 & 263,80 & 183,10 \\
\hline 2011 & 440,35 & 670,07 & 77,93 & 504,27 & 309,69 & 203,37 \\
\hline 2012 & 502,86 & 723,61 & 86,29 & 575,22 & 355,00 & 223,46 \\
\hline $2012 / 2003$ & 568,92 & 367,77 & 202,16 & 402,74 & 994,84 & 410,11 \\
\hline $2007 / 2003$ & 243,81 & 221,45 & 118,22 & 206,95 & 304,73 & 229,97 \\
\hline $2012 / 2008$ & 183,12 & 140,16 & 148,98 & 137,47 & 232,01 & 143,83 \\
\hline
\end{tabular}

Uwaga: W KW mogą wystapić też pozycje ujemne, jak należne wpłaty na KW czy strata netto, stąd suma FU i FZ może przewyższać KW.

Oznaczenia: KW - kapitał własny, FU - fundusz udziałowy, FZ - fundusz zasobowy.

Źródło: Opracowanie własne na podstawie „Monitora Spółdzielczego B”. 
w Mlekpolu, o tyle w drugim podokresie większe tempo wzrostu dotyczyło Mlekovity. Zarówno Mlekovita, jak i Mlekpol w znacznym zakresie powiększyły w badanym okresie wartość funduszu zasobowego; pierwsza spółdzielnia aż 10 razy - do wartości $355 \mathrm{mln}$ zł, a druga czterokrotnie - do wartości $223 \mathrm{mln}$ zł. Mlekovita wykazała przy tym również większe tempo wzrostu w obu podokresach. Wartość funduszu udziałowego mogłaby być większa o wartość należnych wpłat na ten fundusz, czyli w 2003 roku o $13 \mathrm{mln}$ zł w Mlekovicie i 27,8 mln zł w Mlekpolu, a w 2012 roku o 146,2 mln zł w spółdzielni z Grajewa (w 2012 r. w Mlekovicie takie należności nie wystąpiły).

W obu badanych spółdzielniach mleczarskich udział kapitału własnego w kapitale całkowitym wzrósł $\mathrm{w}$ analizowanym okresie o ponad $30 \%$ - do poziomu 0,56 w Mlekovicie i 0,64 w Mlekpolu (tab. 2). Mlekovita w ciagu kilku ostatnich lat ograniczała jego udział na korzyść kapitału obcego. W spółdzielni tej nastapił spadek o prawie 2/3 udziału funduszu udziałowego w kapitale własnym, do poziomu zaledwie 0,17 , przy czym tempo tego spadku wyhamowało $\mathrm{w}$ drugim podokresie.

\section{Tabela 2}

Wybrane wskaźniki struktury kapitału własnego i jego udział w kapitale całkowitym badanych spółdzielni w latach 2003-2012 oraz ich dynamika [\%]

\begin{tabular}{|c|c|c|c|c|c|c|}
\hline \multirow{2}{*}{ Lata i dynamika } & \multicolumn{2}{|c|}{ KW/KC } & \multicolumn{2}{c|}{ FU/KW } & \multicolumn{2}{c|}{ FZ/KW } \\
\cline { 2 - 7 } & SM I & SM II & SM I & SM II & SM I & SM II \\
\hline 2003 & 0,42 & 0,46 & 0,48 & 0,73 & 0,40 & 0,28 \\
\hline 2004 & 0,47 & 0,44 & 0,38 & 0,72 & 0,38 & 0,27 \\
\hline 2005 & 0,53 & 0,52 & 0,34 & 0,73 & 0,42 & 0,30 \\
\hline 2006 & 0,54 & 0,57 & 0,30 & 0,72 & 0,47 & 0,31 \\
\hline 2007 & 0,55 & 0,61 & 0,23 & 0,68 & 0,50 & 0,29 \\
\hline 2008 & 0,60 & 0,61 & 0,21 & 0,81 & 0,56 & 0,30 \\
\hline 2009 & 0,64 & 0,62 & 0,20 & 0,89 & 0,61 & 0,31 \\
\hline 2010 & 0,63 & 0,64 & 0,18 & 0,78 & 0,67 & 0,29 \\
\hline 2011 & 0,59 & 0,63 & 0,18 & 0,75 & 0,70 & 0,30 \\
\hline 2012 & 0,56 & 0,64 & 0,17 & 0,79 & 0,71 & 0,31 \\
\hline $2012 / 2003$ & 132,81 & 138,88 & 35,53 & 109,51 & 174,86 & 111,51 \\
\hline $2007 / 2003$ & 131,16 & 131,05 & 48,49 & 93,45 & 124,99 & 103,85 \\
\hline $2012 / 2008$ & 92,55 & 105,86 & 81,36 & 98,08 & 126,70 & 102,62 \\
\hline
\end{tabular}

Oznaczenia: KC - kapitał całkowity, KW - kapitał własny, FU - fundusz udziałowy, FZ - fundusz zasobowy.

Źródło: Jak w tabeli 1. 
Mlekpol z kolei utrzymywał duży udział tego zmiennego funduszu w kapitale własnym, którego najniższy poziom, tj. 0,68, zanotował w 2007 roku. W ciągu całego badanego okresu jego poziom wzrósł z 0,73 do 0,79 , odnotowując niewielkie tempo spadku w obu podokresach. W spółdzielni tej nie zmienił się znacząco również udział funduszu zasobowego w kapitale własnym. Mlekovita natomiast przyjęła przeciwną strategię i znacząco powiększyła udział tego funduszu w kapitale własnym z 0,40 do 0,71 , a więc o $3 / 4$, utrzymując przy tym jednakowe tempo wzrostu $\mathrm{w}$ obu podokresach.

W obu spółdzielniach rentowność kapitału własnego (ROE) zmniejszyła się - w Mlekovicie o 30\%, a w Mlekpolu o 80\% (tab. 3). Przy czym w tej pierwszej poziom ROE przed kryzysem finansowym wzrósł, a potem spadł, odwrotnie niż w przypadku drugiej spółdzielni. W 2012 roku Mlekovita zanotowała ROE na poziomie $8,35 \%$, czyli ponad czterokrotnie większy niż w Mlekpolu. W obu podmiotach poziom dodatniej dźwigni finansowej zanotował wyraźny spadek, poprawiając się nieznacznie po kryzysie finansowym w spółdzielni Mlekovita.

Istotnym aspektem analizy kapitału własnego przedsiębiorstwa jest ocena efektywności jego wykorzystania, do której wykorzystać można wskaźnik pro-

Tabela 3

Wartość wskaźnika ROE i dźwigni finansowej badanych spółdzielni w latach 2003-2012 oraz ich dynamika [\%]

\begin{tabular}{|c|c|c|c|c|}
\hline \multirow{2}{*}{ Lata i dynamika } & \multicolumn{2}{|c|}{ ROE [\%] } & \multicolumn{2}{c|}{ ROE/ROA } \\
\cline { 2 - 5 } & SM I & SM II & SM I & SM II \\
\hline 2003 & 12,10 & 10,85 & 2,38 & 2,16 \\
\hline 2004 & 18,63 & 9,01 & 2,11 & 2,28 \\
\hline 2005 & 12,35 & 5,43 & 1,89 & 1,93 \\
\hline 2006 & 17,57 & 2,15 & 1,86 & 1,74 \\
\hline 2007 & 23,99 & 9,36 & 1,81 & 1,65 \\
\hline 2008 & 16,20 & 1,06 & 1,66 & 1,65 \\
\hline 2009 & 15,03 & 3,54 & 1,57 & 1,61 \\
\hline 2010 & 8,11 & 3,20 & 1,59 & 1,57 \\
\hline 2011 & 9,95 & 3,61 & 1,70 & 1,59 \\
\hline 2012 & 8,35 & 2,07 & 1,79 & 1,56 \\
\hline $2012 / 2003$ & 69,03 & 19,07 & 75,29 & 72,00 \\
\hline $2007 / 2003$ & 198,30 & 86,28 & 76,24 & 76,31 \\
\hline $2012 / 2008$ & 51,58 & 194,80 & 108,05 & 94,46 \\
\hline
\end{tabular}

Oznaczenia: ROE - rentowność kapitału własnego, ROA - rentowność majątku.

Źródło: Jak w tabeli 1. 


\section{4}

duktywności. Informuje on o zdolności kapitału własnego do generowania przychodów.

Oceniając efektywność wykorzystania kapitału własnego w latach 2003-2012, należy stwierdzić, że wskaźnik produktywności tego kapitału wykazywał w obu spółdzielniach malejącą tendencję do generowania przychodów, co wynikało z mniejszej dynamiki wzrostu przychodów ze sprzedaży niż kapitału własnego (tab. 4). Nieznaczna poprawa nastapiła w drugim podokresie, gdy przychody ze sprzedaży wykazały większą dynamikę wzrostu niż kapitały własne.

W Mlekovicie wzrosła produktywność funduszu udziałowego na skutek większego tempa wzrostu sprzedaży niż tego funduszu, a zmalała produktywność funduszu zasobowego, ponieważ tempo wzrostu sprzedaży było dwukrotnie mniejsze niż w przypadku funduszu zasobowego. W Mlekpolu zmniejszyła się efektywność wykorzystania obu funduszy w wyniku mniejszego tempa wzrostu sprzedaży od tempa wzrostu wartości tych funduszy. Zatem wykorzystanie kapitału własnego i jego składowych w sprzedaży swoich produktów mleczarskich przez obie spółdzielnie (wyjątek to fundusz udziałowy w Mlekovicie) można ocenić jako niewystarczające.

\section{Tabela 4}

Wartość przychodów ze sprzedaży [mln zł] oraz wskaźnika produktywności kapitału własnego i jego składowych w badanych spółdzielni w latach 2003-2012 oraz ich dynamika [\%]

\begin{tabular}{|c|c|c|c|c|c|c|c|c|}
\hline \multirow{2}{*}{$\begin{array}{c}\text { Lata } \\
\text { i dynamika }\end{array}$} & \multicolumn{2}{|c|}{ P } & \multicolumn{2}{c|}{ P/KW } & \multicolumn{2}{c|}{ P/FU } & \multicolumn{2}{c|}{ P/FZ } \\
\cline { 2 - 9 } & SM I & SM II & SM I & SM II & SM I & SM II & SM I & SM II \\
\hline 2003 & 627,87 & 854,44 & 7,10 & 4,34 & 14,71 & 5,98 & 17,60 & 15,68 \\
\hline 2004 & 849,62 & 1271,00 & 7,37 & 5,12 & 19,17 & 7,09 & 19,45 & 18,85 \\
\hline 2005 & 899,08 & 1473,64 & 6,14 & 4,77 & 18,15 & 6,56 & 14,76 & 16,07 \\
\hline 2006 & 980,87 & 1515,84 & 5,67 & 4,15 & 18,99 & 5,73 & 12,05 & 13,30 \\
\hline 2007 & 1337,78 & 1799,36 & 6,21 & 4,13 & 26,51 & 6,09 & 12,30 & 14,36 \\
\hline 2008 & 1370,64 & 1933,18 & 4,99 & 3,74 & 23,66 & 4,62 & 8,96 & 12,44 \\
\hline 2009 & 1733,30 & 2269,11 & 5,09 & 3,92 & 25,81 & 4,43 & 8,29 & 12,81 \\
\hline 2010 & 2331,51 & 2476,44 & 5,95 & 3,97 & 32,33 & 5,09 & 8,84 & 13,53 \\
\hline 2011 & 2338,39 & 2688,70 & 5,31 & 4,01 & 30,01 & 5,33 & 7,55 & 13,22 \\
\hline 2012 & 2765,68 & 2775,68 & 5,50 & 3,84 & 32,05 & 4,83 & 7,79 & 12,42 \\
\hline $2012 / 2003$ & 440,49 & 324,85 & 77,42 & 88,33 & 217,88 & 80,66 & 44,28 & 79,21 \\
\hline $2007 / 2003$ & 213,07 & 210,59 & 87,39 & 95,10 & 180,23 & 101,76 & 69,92 & 91,57 \\
\hline $2012 / 2008$ & 201,78 & 143,58 & 110,19 & 102,44 & 135,44 & 104,45 & 86,97 & 99,83 \\
\hline
\end{tabular}

Oznaczenia: P - przychody netto ze sprzedaży, KW - kapitał własny, FU - fundusz udziałowy, FZ - fundusz zasobowy.

Źródło: Jak w tabeli 1. 
Na podstawie analizy korelacji zmiennych (tab. 5) można stwierdzić, że wartości kapitału własnego, funduszu udziałowego oraz funduszu zasobowego są w obu spółdzielniach bardzo silnie powiązane z wartością sprzedaży i wielkością majątku. W Mlekovicie istnieje silna zależność między wartością kapitału własnego a osiaganą przez nią wielkością zysku netto. W Mlekpolu można zaobserwować ujemną zależność (choć nieistotną statystycznie) między wartością kapitału własnego i jego składowymi a wartością zysku netto. Wynika to z tego, że zysk netto w tej spółdzielni zmalał w badanym okresie z 21,4 do 15,0 mln zł.

Na końcu przystapiono do pogłębionej analizy wskaźnika rentowności kapitału własnego za pomocą modelu Du Ponta [Gup 1987, s. 329-333]. Model ten wskazuje na istotne związki między charakteryzującymi proces efektywnego gospodarowania wskaźnikami, tworząc $\mathrm{z}$ nich zwarty system oceny. $\mathrm{Z}$ modelu wynika, że w analizie przyczynowej wskaźnika rentowności kapitału własnego należy uwzględnić: rentowność sprzedaży netto, rotację majątku (aktywów) posiadanego przez przedsiębiorstwo oraz strukturę kapitału zaangażowanego w przedsiębiorstwie (tzw. mnożnik kapitału własnego) [Bednarski 1997, s. 116]. Można więc przedstawić wskaźnik rentowności kapitałów własnych (ROE) jako iloczyn trzech składników:

$\frac{\text { zysk netto }}{\text { kapitat własny }}=\frac{\text { zysk netto }}{\text { przychody ze sprzedaży }} \times \frac{\text { przychody ze sprzedaży }}{\text { aktywa ogótem }} \times \frac{\text { aktywa ogótem }}{\text { kapitat wtasny }}$

Rentowność netto sprzedaży w badanym okresie zmalała w obu spółdzielniach (tab. 6). W Mlekovicie w pierwszym podokresie wykazała ona istotny wzrost, a w drugim gwałtowny spadek, odwrotnie niż w przypadku Mlekpolu.

Tabela 5

Macierz korelacji między zmiennymi dla Mlekovity (I) i Mlekpolu (II) dla $\alpha=0,05$

\begin{tabular}{|c|c|c|c|c|c|c|c|c|c|c|c|}
\hline SM I & KW & FU & FZ & A & Zn & SMII & KW & FU & FZ & A & Zn \\
\hline KW & 1,00 & & & & & KW & 1,00 & & & & \\
\hline FU & $\mathbf{0 , 9 9}$ & 1,00 & & & & FU & $\mathbf{0 , 9 9}$ & 1,00 & & & \\
\hline FZ & $\mathbf{1 , 0 0}$ & $\mathbf{0 , 9 9}$ & 1,00 & & & FZ & $\mathbf{1 , 0 0}$ & $\mathbf{0 , 9 9}$ & 1,00 & & \\
\hline A & 0,99 & $\mathbf{0 , 9 9}$ & $\mathbf{0 , 9 9}$ & 1,00 & & A & $\mathbf{0 , 9 9}$ & $\mathbf{0 , 9 8}$ & $\mathbf{0 , 9 9}$ & 1,00 & \\
\hline Zn & $\mathbf{0 , 6 5}$ & 0,56 & 0,59 & 0,60 & 1,00 & Zn & $-0,06$ & $-0,13$ & $-0,10$ & $-0,07$ & 1,00 \\
\hline P & $\mathbf{0 , 9 9}$ & $\mathbf{0 , 9 8}$ & $\mathbf{0 , 9 9}$ & $\mathbf{0 , 9 8}$ & 0,59 & P & $\mathbf{0 , 9 9}$ & $\mathbf{0 , 9 7}$ & $\mathbf{0 , 9 9}$ & $\mathbf{0 , 9 9}$ & $-0,01$ \\
\hline
\end{tabular}

Oznaczenia: KW - kapitał własny, FU - fundusz udziałowy, FZ - fundusz zasobowy, A - aktywa ogółem, Zn - zysk netto; Współczynniki korelacji zapisane pogrubioną czcionką są istotne statystycznie.

Źródło: Opracowanie własne. 


\section{Tabela 6}

Wartość wskaźnika rentowności sprzedaży, produktywności majątku oraz mnożnika kapitału własnego badanych spółdzielni w latach 2003-2012 oraz ich dynamika [\%]

\begin{tabular}{|c|c|c|c|c|c|c|}
\hline \multirow{2}{*}{$\begin{array}{c}\text { Lata } \\
\text { i dynamika }\end{array}$} & \multicolumn{2}{|c|}{ ROS [\%] } & \multicolumn{2}{c|}{ P/A } & \multicolumn{2}{c|}{ A/KW } \\
\cline { 2 - 7 } & SM I & SM II & SM I & SM II & SM I & SM II \\
\hline 2003 & 1,70 & 2,50 & 2,99 & 2,01 & 2,38 & 2,16 \\
\hline 2004 & 2,53 & 1,76 & 3,49 & 2,25 & 2,11 & 2,28 \\
\hline 2005 & 2,01 & 1,14 & 3,25 & 2,48 & 1,89 & 1,93 \\
\hline 2006 & 3,10 & 0,52 & 3,05 & 2,38 & 1,86 & 1,74 \\
\hline 2007 & 3,87 & 2,27 & 3,42 & 2,50 & 1,81 & 1,65 \\
\hline 2008 & 3,24 & 0,28 & 3,01 & 2,27 & 1,66 & 1,65 \\
\hline 2009 & 2,95 & 0,90 & 3,25 & 2,44 & 1,57 & 1,61 \\
\hline 2010 & 1,36 & 0,80 & 3,73 & 2,53 & 1,59 & 1,57 \\
\hline 2011 & 1,87 & 0,90 & 3,12 & 2,53 & 1,70 & 1,59 \\
\hline 2012 & 1,52 & 0,54 & 3,07 & 2,46 & 1,79 & 1,56 \\
\hline $2012 / 2003$ & 89,16 & 21,59 & 102,83 & 122,67 & 75,29 & 72,00 \\
\hline $2007 / 2003$ & 226,91 & 90,73 & 114,62 & 124,62 & 76,24 & 76,31 \\
\hline $2012 / 2008$ & 46,81 & 190,16 & 101,98 & 108,44 & 108,05 & 94,46 \\
\hline
\end{tabular}

Oznaczenia: ROS - rentowność netto sprzedaży, A - aktywa ogółem, P - przychody netto ze sprzedaży, KW - kapitał własny.

Źródło: Jak w tabeli 1.

Wykorzystanie majątku w okresie 2003-2012 w Mlekovicie praktycznie się nie zmieniło, a w Mlekpolu poprawiło. Ze względu na wyraźne zmniejszenie się poziomu ROS i poprawę produktywności majątku można wnioskować [Pazio 1994, s. 315], że Mlekpol realizował politykę ilości. Mlekovita natomiast, zachowując przez cały czas większą produktywność majątku oraz bardzo dobrą rentowność handlową, realizowała strategię jakości. Zmniejszenie się wartości mnożnika kapitału własnego na przestrzeni badanych 10 lat wynikało z tego, że tempo wzrostu wartości kapitału własnego przewyższało tempo wzrostu wartości majątku i udział kapitału własnego w strukturze pasywów wzrasta1.

Następnie zbadano zależności przyczynowo-skutkowe występujące między wskaźnikami ekonomicznymi w modelu du Ponta. Celem było ustalenie wpływu rentowności sprzedaży, produktywności majątku oraz mnożnika kapitału własnego na kształtowanie się poziomu ROE. Przy obliczaniu wpływu poszczególnych czynników na odchylenie bezwzględne wskaźnika ROE skorzystano z metody 
funkcyjnej, która jest najbardziej poprawna z punktu widzenia matematycznego, ponieważ wynik analizy nie zależy od kolejności wykonywanych działań [Nowak 2005, s. 60].

Na spadek w latach 2003-2012 rentowności kapitału własnego w Mlekovicie o 3,75 p.p. największy wpływ miał malejący mnożnik kapitału własnego (tab. 7). Pogorszenie rentowności sprzedaży w tej mleczarni spowodowało spadek ROE o 1,16 p.p. Niewielki wzrost produktywności majątku poprawił ROE - o 0,28 p.p. W przypadku Mlekpolu na spadek poziomu ROE o 8,78 p.p. największy wpływ miało bardzo silne (bo o 78,41\%) zmniejszenie wartości ROS. Zmiana ta spowodowała spadek ROE o 8,1 p.p. Negatywnie na poziom ROE wpłynęło też zmniejszenie mnożnika kapitału własnego, pozytywny wpływ miała zaś poprawa produktywności majątku. W pierwszym podokresie ROE w Mlekovicie istotnie się poprawiło, na co wpływ miał przede wszystkim bardzo duży (ponad dwukrotny) wzrost ROS oraz wzrost produktywności majątku. Poziom ROE obniżał (o 5,09 p.p.) istotny spadek mnożnika kapitału własnego. W Mlekpolu w tym okresie nastapiło zaś niewielkie pogorszenie wartości ROE, za który odpowiadał głównie zmniejszony mnożnik kapitału własnego oraz spadek ROS. Te ujemne działania niwelował wzrost (o 1/4) produktywności majątku. W okresie 2008-2012 w Mlekovicie na spadek rentowności finansowej (o 9,05 p.p.) wpływ miało znaczące (bo o 53\%) pogorszenie ROS. W nieznacznym stopniu niwelowały to wzrosty produktywności majątku oraz mnożnika kapitału własnego. W latach po kryzysie finansowym Mlekpol poprawił nieznacznie poziom ROE (o 1,01 p.p.). Poprawa o $90 \%$ wartości ROS spowodowała wzrost ROE jedynie o 0,97 p.p. Niewielki wzrost produktywności majątku poprawił poziom ROE o 0,13 p.p. Negatywny wpływ na ROE miało natomiast pogorszenie wartości mnożnika kapitału własnego.

Tabela 7

Analiza przyczynowa rentowności kapitału własnego badanych spółdzielni w latach 2003-2012

\begin{tabular}{|c|c|c|c|c|c|c|c|c|}
\hline \multirow{2}{*}{ Okres } & \multicolumn{4}{|c|}{ Wartość wpływu czynników na zmiany ROE } & \multirow{2}{*}{$\begin{array}{c}\text { Odchylenie bezwzględne } \\
\text { ROE [p.p.] }\end{array}$} \\
\cline { 2 - 8 } & \multicolumn{2}{|c|}{ ROS } & \multicolumn{2}{|c|}{ P/A } & \multicolumn{2}{|c|}{ A/KW } & \multicolumn{2}{c|}{} \\
\cline { 2 - 8 } & SM I & SM II & SM I & SM II & SM I & SM II & SM I & SM II \\
\hline $2003-2012$ & $-1,16$ & $-8,10$ & 0,28 & 1,33 & $-2,87$ & $-2,01$ & $-3,75$ & $-8,78$ \\
\hline $2003-2007$ & 14,48 & $-0,99$ & 2,50 & 2,25 & $-5,09$ & $-2,75$ & 11,89 & $-1,49$ \\
\hline $2008-2012$ & $-9,05$ & 0,97 & 0,24 & 0,13 & 0,97 & $-0,09$ & $-7,84$ & 1,01 \\
\hline
\end{tabular}

Oznaczenia jak w tabeli 6.

Źródło: Opracowanie własne. 


\section{Wnioski}

Wyniki przeprowadzonej analizy pozwalają na następujące stwierdzenia:

1. Badane spółdzielnie mleczarskie w latach 2003-2012 osiągnęły dużą koncentrację kapitału własnego. Pierwsza z nich o stosunkowo małej (o 55\%) początkowej jego wartości osiagnęła przyrost tego kapitału 5,7-krotny, a druga o większej początkowej wartości - wzrost 3,7-krotny. Mlekovita w obu podokresach osiagała większą dynamikę przyrostu kapitału własnego niż Mlekpol.

2. Badane spółdzielnie mleczarskie realizowały nieco odmienne strategie koncentracji kapitału własnego w latach 2003-2012. Mlekovita zwiększała głównie fundusz zasobowy (wzrost dziesięciokrotny przy dwukrotnym wzroście wartości funduszu udziałowego), a Mlekpol powiększał wartość w równym stopniu funduszu udziałowego i funduszu zasobowego (wzrosty czterokrotne).

3. Znacząca koncentracja kapitału własnego $\mathrm{w}$ analizowanych spółdzielniach w latach 2003-2012, przy rosnących w mniejszym tempie pozostałych źródłach finansowania majątku, spowodowała wzrost udziału tego kapitału w kapitale ogółem tych spółdzielni. Ten wzrost udziału kapitału własnego niewątpliwie podniósł poziom bezpieczeństwa finansowego analizowanych spółdzielni mleczarskich.

4. Duża koncentracja kapitału własnego analizowanych spółdzielni przyczyniła się też niewątpliwie do dużego wzrostu wartości ich kapitału ogółem, a tym samym do znaczącego podniesienia wartości majątku tych spółdzielni oraz potencjału produkcyjnego i przychodów ze sprzedaży. Wartość tych ostatnich w analizowanym okresie w pierwszej mleczarni wzrosła o $340,5 \%$, a w drugiej o $224,9 \%$. Te znaczące wzrosty wartości przychodów sprzedaży obu mleczarni niewątpliwie umocniły ich pozycje na konkurencyjnym, unijnym rynku mleka. Będzie to szczególnie istotne zarówno dla tych spółdzielni, jak i ich członków-dostawców mleka, kiedy niebawem przestaną obowiązywać kwoty mleczne na tym rynku.

5. W analizowanym okresie wzrost udziału kapitału własnego w kapitale całkowitym badanych mleczarni spowodował obniżenie ich efektu dźwigni finansowej, które w Mlekovicie wyniosło 0,59 (z 2,38 do 1,79), a w Mlekpolu 0,60 (z 2,16 do 1,56). To obniżenie efektu dźwigni finansowej analizowanych spółdzielni miało m.in. wpływ na obniżenie poziomu rentowności ich kapitału własnego.

6. Na pogorszenie się rentowności finansowej w obu podmiotach w latach 2003-2013 wpływ miał spadek rentowności sprzedaży i mnożnika kapitału własnego. Mnożnik kapitału własnego malał ze względu na niedostosowane tempo wzrostu majątku do tempa wzrostu kapitału własnego. 
Pozytywnie natomiast na wartość wskaźnika ROE oddziaływał wzrost produktywności majątku.

7. Wykorzystanie kapitału własnego i jego składowych w sprzedaży swoich produktów mleczarskich przez obydwie spółdzielnie (wyjątek to fundusz udziałowy w Mlekovicie) można ocenić jako niewystarczające i należałoby szukać możliwości w sprawniejszym zarządzaniu kapitałem własnym.

8. W obu spółdzielniach wartości kapitału własnego oraz funduszu udziałowego i funduszu zasobowego są bardzo silnie powiązane $\mathrm{z}$ wartością sprzedaży. W Mlekovicie istnieje silny związek między wartością kapitału własnego a wielkością zysku netto. W przypadku Mlekpolu zaobserwowano ujemną zależność z kapitałem własnym i jego składowymi, choć nieistotną statystycznie.

9. Uzyskane wyniki analizy koncentracji kapitału własnego oraz jego efektywności w obydwu spółdzielniach mleczarskich różnią się znacząco pomiędzy rozpatrywanymi okresami. W latach 2003-2007 w porównaniu z latami 2008-2012 (kryzysu finansowego) obie mleczarnie osiagnęły znacznie większą dynamikę koncentracji kapitału własnego, a także znacząco wyższe średnie poziomy efektywności tego kapitału i jego składników.

\section{Literatura}

BEDNARSKI L., 1997: Analiza finansowa w przedsiębiorstwie, PWE, Warszawa.

BRODZIŃSKI M.G., 1993: Bariery wzrostu i kierunki powiazań integracyjnych spółdzielni mleczarskich $z$ rolnikami $w$ zakresie produkcji i skupu mleka o wysokim standardzie jakościowym, [w:] Spółdzielczość rolnicza w gospodarce rynkowej, (red.) E. Pudełkiewicz, Z.T. Wierzbicki, Spółdzielczy Instytut Badawczy, Warszawa

BRODZIŃSKI M.G., 2014: Oblicza polskiej spółdzielczości wiejskiej. Geneza - rozwój - przyszłość, Wydawnictwo Frel, Warszawa.

DWORNIAK J., 2009: Fundusze własne a sytuacja finansowa spółdzielni mleczarskich, Zeszyty Naukowe SGGW, Ekonomika i Organizacja Gospodarki Żywnościowej 78.

DWORNIAK J., 2010: Strategie finansowania spółdzielni mleczarskich, Zeszyty Naukowe SGGW, Ekonomika i Organizacja Gospodarki Żywnościowej, 82.

DWORNIAK J., WASILEWSKI M., 2007: Fundusz udziałowy a sytuacja finansowa spótdzielni mleczarskich, Roczniki Nauk Rolniczych, Seria G, 93.

FALKOWSKI J., MALAK-RAWLIKOWSKA A., MILCZAREK-ANDRZEJEWSKA S., 2007: Restrukturyzacja sektora mleczarskiego w Polsce. Przyczyny i skutki, Roczniki Nauk Rolniczych, Seria G, 94.

GUP B. E., 1987: Principles of Financial Management, John Wiley and Sons, New York.

JANCZEWSKI S., 1990: Prawo handlowe, wekslowe i czekowe, Warszawa.

KAPUSTA F., 2011: Konsolidacja mleczarstwa pilna potrzeba, „Przegląd mleczarski” 4.

KOMOROWSKA D., 2006: Koncentracja produkcji mleka w Polsce, Zeszyty Naukowe SGGW Ekonomika i Organizacja Gospodarki Żywnościowej 61.

KRUCZALAK K., 1996: Prawo handlowe, Zarys wykładu, Warszawa. 
MIERZWA D., 2005: W poszukiwaniu nowego modelu spółdzielczości rolniczej, Wydawnictwo Akademii Rolniczej we Wrocławiu, Wrocław.

NOWAK E., 2005: Analiza sprawozdań finansowych, PWE, Warszawa.

PARZONKO A., 2013: Globalne i lokalne uwarunkowania rozwoju produkcji mleka, Wyd. SGGW, Warszawa.

PAZIO W., 1994: Jak gospodarować finansami. Ekonomiczne podstawy biznesu, PWN, Warszawa.

PIETRZAK M., 2006: Efektywność finansowa spółdzielni mleczarskich - koncepcja oceny, Wyd. SGGW, Warszawa.

SEREMAK-BULGE J. (red), 2005: Rozwój rynku mleczarskiego i zmiany jego funkcjonowania w latach 1990-2005, IERiGŻ-PIB, Warszawa.

SEREMAK-BULGE J., 2013: Restrukturyzacja produkcji mleka, Przegląd Mleczarski 9.

SEREMAK-BULGE J., 2014: Przetwórstwo mleka, Rynek Mleka 46, 11-13.

STELMACHOWSKI A., 1998: Zarys teorii prawa cywilnego, Warszawa.

SZAJNER P., 2011: Międzynarodowa konkurencyjność polskiego sektora mleczarskiego $w$ kontekście wyników handlu zagranicznego, Zeszyty Naukowe SGGW w Warszawie. Problemy Rolnictwa Światowego 11(26).

SZCZUBEŁEK G., 2011: Uwarunkowania rozwoju przedsiębiorstw przemystu mleczarskiego w Polsce, Wydawnictwo „Dom Organizatora”, Toruń.

ZAKRZEWSKI P., 2003: Majatek spótdzielni, Wyd. Prawnicze LexisNexis, Warszawa.

ZUBA M., ZUBA J., 2012: Wplyw liczby gospodarstw sprzedajacych mleko do spótdzielni mleczarskich na ich rentowność i bezpieczeństwo finansowe, Roczniki Naukowe Stowarzyszenia Ekonomistów Rolnictwa i Agrobiznesu XIV, 1.

Ustawa Prawo spółdzielcze z 16 września 1982 (Dz.U. z 1995 r. nr 54, poz. 288 z późn. zm.).

GUS, 2012: Rocznik Statystyczny Rolnictwa 2012, Warszawa, s. 110.

GUS, 2013: Rocznik Statystyczny Rolnictwa 2013, Warszawa, s. 258.

Lista 2000. Polskie przedsiębiorstwa, 2013: Wyd. Rzeczpospolita, Warszawa.

Mlekpol, witryna internetowa MS http://www.mlekpol.com.pl/index.php?option=com_content\&view $=$ article \&id $=5$ :informacje-ogolne \&catid=2: uncategorised\&Itemid $=344$ (data dostępu: 30.07.2014).

Mlekovita, witryna internetowa MS http://www.mlekovita.com.pl/php/o-mlekovicie/ (data dostępu: 30.07.2014).

\section{The influence of the concentration of equity capital on its efficiency in selected milk cooperatives in Poland in years 2003-2012}

\section{Abstract}

The aim of the work was to analyse and evaluate the impact of the concentration of equity capital on its efficiency on the example of two biggest milk cooperatives in Poland (SM Mlekovita and SM Mlekpol). Except of standard 
appraisal factors of the efficiency of the considered capital, indicators of the productivity of equity capital altogether and its fundamental components were applied. In years 2003-2012 examined milk cooperatives were characterized by large concentration of equity capital, realizing somewhat different strategies of its concentration. Large concentration of equity capital significantly improved the value of the property of these cooperatives, as well as their sales revenue. In both co-operatives the worsening of the financial profitability was caused by a fall of the sales profitability as well as the multiplier of the equity capital. However, the growth of the capital productivity positively influenced the value of the indicator ROE. The productivity of the equity capital and its components fell. The principal amounts of the equity capital and the shareholding fund and capital fund are very strongly related to the sales value. 
